\title{
СУДОВА ФАРМАЦІЯ ТА МЕДИЦИНА: РИЗИКИ ДЛЯ ФАРМАКОТЕРАПІЇ АДИКТИВНОЇ ЗАЛЕЖНОСТІ ТА ПРОТИДІЇ НЕЗАКОННОГО ОБІГУ ПСИХОАКТИВНИХ РЕЧОВИН В УМОВАХ ПАНДЕМІї COVID-19
}

\section{FORENSIC PHARMACY AND MEDICINE: RISKS FOR PHARMACOTHERAPY OF ADDICTION AND COUNTERING OF ILLEGAL CIRCULATION OF PSYCHOACTIVE SUBSTANCES IN THE COVID-19 PANDEMIC}

Ігор Гайдучок (Ihor Hayduchok) ${ }^{1}$, Валерій Шаповалов (Valerii Shapovalov) $)^{1,2,3}$

1 ТзОВ «Львівській медичний інститут», Львів, Україна (Lviv Medical Institute LLC, Lviv, Ukraine)

2 Національна асоціація адвокатів України, Київ, Україна (Ukrainian National Bar Association, Kyiv, Ukraine)

3 Адвокатське об'сднання «Апофеоз», Харків, Україна (Advocates Company "Apotheosis", Kharkiv, Ukraine)

${ }^{*}$ Corresponding author: Ihor Hayduchok
Received: November 29, 2021

Published: December 10, 2021
Abstract. Conducted forensic and pharmacological study of international experience of the risks of pharmacotherapy of addiction and countering of illegal circulation of psychoactive substances in the context of the COVID-19 pandemic. Psychoactive substances include narcotic drugs, psychotropic substances, precursors, psychoactive drugs. Noted that in modern conditions of pandemic and its new strain "Omicron" intensifies anti-epidemic measures in all countries of the world, which requires the healthcare system, especially in Ukraine, to concentrate healthcare, finance and medicine for vaccination of citizens of all ages, pharmacotherapy of comorbid, concomitant, dual, addictive disorders on the background of coronavirus disease. The experience of the world's leading countries on the risks of the spread of illegal circulation of psychoactive substances of different classification and legal groups was studied. It has been established that the demand for illegal psychoactive substances grows, and the globalization of the drug business is stabilizing in the form of transnational organized criminal drug groups. This makes it necessary for the legislature to constantly increase criminal liability for illegal circulation of psychoactive substances, drugs, psychotropic substances, precursors, psychoactive drugs. Noted that the relevant police and operational services should constantly improve the level and system of prevention and control of illegal circulation of psychoactive substances. At the same time, stricter liability should be provided for the actions of members of organized criminal drug circulation groups for the sale 
(production, modification of storage, transportation, transfer of trade, etc.) of psychoactive substances of different classification and legal groups, including for profit in large quantities and especially large amounts. Rulemaking initiatives to the Article 307 of the Criminal Code of Ukraine were developed and proposed.

Keywords: forensic pharmacy, forensic medicine, addiction, pharmacotherapy, illegal circulation, psychoactive substances, psychotropic substances, precursors.

Вступ. Судово-фармацевтичні дослідження свідчать про те, що адиктивні розлади здоров'я (наркотична, алкогольна та ін. залежності) поєднуються із супутніми, дуальними, коморбідними захворюваннями (порушення імунної, серцево-судинної, гепатобіліарної, шлунково-травневою, дихальною систем, системи кровообігу, зору, ВІЛ/СНІД, туберкульоз тощо). 3 іншого боку, хворі на адиктивну залежність скоюють злочини (крадіжки, вбивства, грабежі, дорожньотранспортні пригоди, приймають участь у збуті психоактивних речовин різних класифікаційно-правових груп: наркотичні засоби (Н3), психотропні речовини (ПР), прекурсори та ін. [1-10].

Вивчення з позиції судової фармації ризиків фармакотерапії адиктивної залежності та протидії незаконному обігу психоактивних речовин (ПАР) в умовах пандемії COVID-19 є актуальним тому, що саме хворі на адиктивну залежність 3 дуальними розладами у першу чергу потребують вчасної безоплатної (виключно за рахунок держави) медичної допомоги, фармацевтичного забезпечення, фармакотерапії та соціально-економічної реабілітації [11-15].

Вчені, представники органів влади, лікарі та журналісти [16] уважно стежать за новим нащадком Delta-варіанту Covid, який викликає зростаючу кількість інфекцій у Великій Британії. За АY.4.2 - «Дельта плюс», що містить зміни (мутації), які потенційно можуть допомогти вірусу вижити більш ефективно. Водночас зазначається, що у всьому світі циркулюють тисячі різних типів або варіантів Covid-19. Один із них, відомий як «Дельта або В.1.617.2», був вперше виявлений в Індії. Лікарі та керівники системи охорони здоров'я Великобританії зазначають, що штам «Дельта» стала домінуючим варіантом у 
країні. У липні 2021 року фахівці виявили новий штам АY.4.2. Інші поточні варіанти, що викликають тривогу у фахівців, включають:

Альфа (В.1.1.7), вперше виявлений у Великій Британії, поширився на більш ніж 50 країн;

Бета (В.1.351), вперше виявлений у Південній Африці, також виявлений у 20 інших країнах, включаючи Велику Британію;

Гамма (Р.1), вперше виявлений в Бразилії, також виявлений у більш ніж 10 інших країнах, включаючи Велику Британію.

Слід зазначити, що вчені з Південної Африки поспішають дослідити та простежити тривожне зростання нового варіанта коронавірусу, що викликає Covid-19, який містить велику кількість мутацій, виявлених в інших варіантах, включаючи Delta, i, схоже, швидко поширюється Південною Африкою [17]. Дослідники виявили В.1.1.529 даних секвенування геному з Ботсвани. Варіант виділявся тим, що він містить понад 30 змін у шиповому білку - білку SARSCoV-2, який розпізнає клітини-господарі та $є$ основною мішенню імунних відповідей організму. Також, багато змін було виявлено в таких варіантах, як «Дельта» та «Альфа», і пов'язані з підвищеною інфекційністю та здатністю уникати антитіл, що блокують інфекцію. Але очевидне різке зростання цього варіанту Covid-19, що викликає, в південноафриканській провінції Гаутенг (Gauteng), де знаходиться Йоганнесбург (Південна Африка), також викликає тривогу вчених, які встановили, що в листопаді 2021 року в провінції різко зросла кількість випадків захворювання, особливо в школах і серед молоді. Секвенування геному та інший генетичний аналіз, проведений лікарями, у період з 12 по 20 листопада, показали, що варіант В.1.1.529 був відповідальний за всі 77 зразків вірусу.

Отже, сьогодні вкрай необхідним $є$ судово-фармацевтичне вивчення міжнародного досвіду щодо ризиків для фармакотерапії адиктивної залежності та протидії незаконного обігу ПАР в умовах пандемії COVID-19, що і склало мету роботи. 
Матеріали та методи. Інформаційну базу дослідження склали наукові праці іноземних та вітчизняних вчених за темою статті, зокрема [18-23], складовими яких виступають наркологія, психіатрія, неврологія, клінічна фармація, імунологія, екологія, судова фармація, фармацевтичне та медичне право. Огляд наукових джерел літератури було проведено із врахуванням рекомендацій Кокрейнівського товариства за PICO: P (population) - населення, що страждає на адиктивну залежність; I (intervention) - фармакотерапія, ефективні, безпечні, доступні ліки; С (comparator) - технологія дослідження; О (outcomes) - результати дослідження. В якості методів дослідження використано нормативно-правовий, документальний, ретроспективний, порівняльний, системний, табличний, судово-фармацевтичний та графічний. Для обробки результатів, визначення узгодженості між досліджуваними параметрами використано програму Microsoft Excel 2010 (описові характеристики: мінімальне та максимальне значення, середнє значення).

Дослідження статті $\epsilon$ фрагментом науково-дослідних робіт ТзОВ «Львівський медичний інститут» за темою «Удосконалення системи обігу ліків під час фармакотерапії на засадах доказової і судової фармації, організації, технології, біофармації та фармацевтичного права» (номер державної реєстрації 0120U105348, термін виконання 2021-2026), Харківської медичної академії післядипломної освіти за темами «Удосконалення організаційно-правової процедури забезпечення ліками пацієнтів з позиції судової фармації, організації і управління фармацією» (номер державної реєстрації 0116U003137, термін виконання 2016-2020рр.) та «Фармацевтичне та медичне право: інтегровані підходи до системи обігу ліків з позиції судової фармації та організації фармацевтичної справи» (номер державної реєстрації 0121 U000031, термін виконання 2021-2026 рр.).

Результати та їх обговорення. За даними Francois Balloux, директора Інституту генетики (Director of the UCL Genetics Institute), вipyc UCL B.1.1.529, ймовірно, виник під час хронічної інфекції людини з ослабленим імунітетом, можливо, у нелікованого пацієнта з ВІЛ/СНІДом [24]. При цьому вчені 
стверджують, що при 8,2 мільйонах людей, інфікованих на ВІЛ/СНІД, що є найбільшим числом у світі, зусилля Південної Африки щодо боротьби 3 пандемією коронавірусу були складними, щеплення знаходиться на низькому рівні, оскільки люди з ослабленим імунітетом можуть довше зберігати вірус, тем більше, які вживали велику кількість різних медикаментів «коктейлю», що послабили імунну систему та спричинили розвиток в організмі системних захворювань [25-29].

Вперше про варіант В.1.1.529 було повідомлено у ВООЗ з Південної Африки 24.11.2021 [30]. Епідеміологічна ситуація в цьому регіоні характеризувалася трьома виразними піками у зареєстрованих випадках, останній з яких був переважно дельта-варіантом. Аналіз показав, що останніми тижнями кількість інфекцій різко зросла, що збіглося з виявленням у зразку (09.11.2021) першої інфекції варіанту В.1.1.529, при цьому він має:

- велику (більше ніж 50) кількість мутацій, деякі з яких викликають занепокоєння;

- пाдвищений ризик повторного зараження цим варіантом, порівняно 3 іншими.

Під час засідання експертів ВООЗ позначила В.1.1.529 під назвою «Omicron». ВООЗ пропонує країнам дотримуватися наступного:

$\checkmark \quad$ посилити епіднагляд та встановити послідовність, щоб краще зрозуміти циркулюючі варіанти SARS-CoV-2;

$\checkmark$ надсилати повні послідовності геному та пов'язані метадані в загальнодоступну базу даних, таку як GISAID;

$\checkmark \quad$ повідомляти ВООЗ про перші випадки/кластери, пов'язані $з$ інфекцією ЛОС, через механізм ММСП;

$\checkmark \quad$ за наявності потенціалу та у координації з міжнародним співтовариством проводити польові дослідження та лабораторні оцінки для покращення розуміння потенційного впливу ЛОС на епідеміологію COVID-19, серйозність, ефективність заходів громадської охорони здоров'я та соціальних заходів, 
методи діагностики, імунні реакції, антитіла. нейтралізація чи інші відповідні характеристики.

Крім того, громадянам нагадують про необхідність вжити заходів для зниження ризику зараження COVID-19, включаючи перевірені заходи громадської охорони здоров'я та соціально-профілактичні заходи, а саме: носіння масок; гігієна рук; фізичне дистанціювання; поліпшення вентиляції приміщень; уникнення людних місць; вакцинація (ревакцинація).

Влада більшості держав світу з тривогою відреагувала на появу штаму «Омікрон», який вперше був виявлений у Південній Африці і з того часу був виявлений вже у Бельгії, Ізраїлі, Ботсвані та Гонконгу [31]. Свропейський союз і Великобританія запровадили обмеження для мандрівників із кількох країн на півдні Африки, оскільки дослідники намагаються з'ясувати, чи була мутація стійкою до вакцин, тоді як Сполучені Штати оголосили, що аналогічні обмеження розпочнуться у понеділок 29.11.2021. Експерт ВОО3 Maria Van Kerkhove заявила, що, ймовірно, потрібно кілька тижнів, щоб визначити, наскільки ефективними $є$ існуючі вакцини проти COVID-19 щодо нового варіанту В.1.1529 «Omicron». Викладач фармацевтичної школи Лондонського університетського коледжу Oksana Pyzik зазначила [32], що, на ïi думку, новий варіант «Omicron» не повинен стати сюрпризом» на тлі попереджень ВООЗ про те, що глобальна несправедливість щодо вакцин може призвести до появи нових штамів вірусу внаслідок пандемії на COVID-19.

Мутаціï SARS-CoV-2 нового варіанту B.1.1529 «Omicron» знаходяться у причинно-наслідкових зв’язках з імунологією пацієнтів. Фармакотерапія може супроводжуватися ризиками внаслідок неналежної медичної допомоги, неналежного фармацевтичного забезпечення, фальсифікованих ліків тощо. Серед коморбідних та супутніх у таких пацієнтів можуть бути ВІЛ/СНІД, туберкульоз, наркотична залежність, тобто хвороби, що супроводжуються болями різного генезу і потребують протибольові лікарські засоби (ЛЗ). Серед анальгетиків найпоширенішою є класифікаційно-правова група ПАР НЗ, вони мають психоактивні властивості, є наркотичними засобами, які виписує саме 
лікар, а відпускає із аптеки провізор (фармацевт). Відсутність належного доступу вказаної категорії пацієнтів до відповідної - легальної фармакотерапії у ланцюзі правовідносин «лікар-пацієнт-провізор» викликає у пацієнта потребу у доступі до заборонених для обігу НЗ, що є злочином з боку осіб, які злочинно (кримінально) збувають ПАР НЗ, ПР, прекурсори. Зазначене вимагає від Кабінету міністрів України, МО3 України та МВС України скоординувати роботу відповідних міністерств щодо дійової процедури по ізоляції громадян України та іноземних громадян (насамперед, з країн Африки), що не пройшли щеплення (потребують 14-ти денний ізольований карантин та тестування). Вказані дії будуть сприяти попередженню причини і умов розповсюдження COVID-19, ВІЛ/СНІДу, туберкульозу та адиктивної залежності.

Разом 3 тим, важливим моментом в оптимізації стратегії державної політики України до 2035 року щодо протидії незаконного обігу ПАР НЗ в умовах пандемії на COVID-19 є вивчення ефективності державної політики провідних країн світу (США, Канада, Італія, Німеччина, Великобританія) у протидії незаконного обігу НЗ, боротьбі з організованим транснаціональним, регіональним та прикордонним наркобізнесом.

Як стверджує Bridget G. Brennan, спеціальний прокурор м. Нью-Йорк по боротьбі з ПАР НЗ, в США «...не розвивалася опіоїдна епідемія до тих пір, поки не був величезний надлишок опіоїдів, який розпочався 3 фармацевтичних препаратів...» [33].

За даними Організації Об’єднаних Націй, вживання ПАР, Н3, ПР, прекурсорів у світі зросло на 22\% у порівнянні з 2010 р., що пов'язано із безпрецедентними потрясіннями для кожної людини, спричиненими пандемією COVID-19. Криза, що пов'язана із COVID-19, втрата в країнах світу 255 мільйонів робочих місць у 2020 році, підштовхнула більш ніж 100 мільйонів людей в умовах крайньої бідності, і значного загострення безробіття та нерівності, погіршення їх психічного здоров'я, а як наслідок зловживання ПАР i росту захворюваності у відповідності до МКХ-11 [34]. 
Більше того, під час пандемії вже спостерігалися зміни у структурі вживання ПАР різних класифікаційно-правових груп, включаючи зростання вживання канабісу (H3) та немедичне використання психоактивних седативних ЛЗ. Основні соціально-економічні чинники стресу (безробіття, низка зарплатня, обмеження, висока смертність, супутні захворювання тощо) також, мабуть, збільшили попит на зловживання ПАР та психоактивних ЛЗ [35].

Наступним завданням дослідження було судово-фармацевтичне вивчення міжнародного досвіду щодо ризиків фармакотерапії адиктивної залежності та протидією незаконному обігу ПАР в умовах пандемії COVID-19 на прикладі окремих країн світу. Так, федеральним урядом США в рамках дорожньої карти розроблена програма з надання професійної допомоги правоохоронним службам країн, щодо яких є оперативно-розшукові дані по контрабанді ПАР різних класифікаційно-правових груп в США. Прикладом є «Plan Colombia» [36], активна реалізація якого здійснювалася в період з 2000 по 2015 роки, метою якого $є$ боротьба з дією організованих злочинних наркоугрупувань, що пов'язана 3 контрабандним обігом (перевезенням, зберіганням, постачанням) в країну Н3 кокаїну через країни Центральної Америки та Мексику. Серед заходів такого плану було навчання підрозділів колумбійської армії та поліції, а також їх оснащення відповідною спеціальною технікою та спеціальними приладами.

Відзначено про дуже помітну різницю у підходах між Венесуеллою, Панамою, Бразилією, Європейським Союзом, Францією та Сполученими Штатами у реалізації «Plan Colombia» [37]. У Колумбії присутні всі елементи тривалої кризи: внутрішній конфлікт між марксистськими партизанами та членами вкрай правих ополченців, контроль за виробництвом ПАР НЗ, П, прекурсорів, спроба уряду відновити мир у світі та відновити контроль над територією; бажання США втрутитися, щоб покласти край незаконному обігу ПАР НЗ, ПР, прекурсорів. Фінансовий внесок СС у розмірі 871 млн доларів здебільшого спрямований на «інституційне посилення» та «соціальний розвиток». Водночас країни, що межують з Колумбією (Еквадор, Перу, Бразилія, Венесуела та Панама) побоюються, що насильницький наступ на виробництво 
ПАР НЗ, ПР, прекурсорів призведе до поширення і зростання контрабанди ПАР. Слід зазначити, що пандемія COVID-19 у США погіршує епідеміологічну ситуацію, спостерігається зростання коморбідних розладів, що супроводжується судово-фармацевтичними ризиками у фармакотерапії адиктивної залежності та протидії незаконного обігу ПАР Поєднання COVID-19 3 адиктивною захворюваністю (наркотична, алкогольна, полінаркоманія та ін.) супроводжується летальними випадками від передозування внаслідок зловживання ПАР по всій країні. Близько сімдесяти тисяч людей померли від передозування Н3 опіоїдів у 2020 р., що є найвищим показником за всю історію спостережень. Фентаніл та інші синтетичні опіоїди стали рушійною силою кризи в останні роки, при цьому дедалі більша частка постачань надходить із Мексики. Понад 1300 людей на тиждень помирають від передозувань, пов'язаних з Н3 опіоїдами, і ця цифра різко зростає по всій країні на тлі пандемії COVID-19. Тим часом мільйони американців страждають від адиктивної опіоїдної залежності. Криза досягла таких масштабів, що стала гальмом для економіки та загрозою національній безпеці. Аналітики відмічають, що проблема почалася з надмірного прийому легальних анальгетичних ЛЗ, але останніми роками вона посилилася 3 незаконним обігом НЗ героїну та ПАР інших класифікаційно-правових груп [38].

Великий інтерес викликає справа Верховного суду штату Вашингтон «Штат проти Блейка» (25.02.2021 р.) щодо оголошення неконституційним закон Вашингтона стосовно суворої відповідальності за зберігання ПАР НЗ, який де факто криміналізував ненавмисне зберігання контрольованих ПАР без рецепту 3 незнання [39]. Це рішення мало величезний вплив на округи та міста по всьому штату. Законодавчий орган штату та деякі місцеві органи влади розглядають наступні можливі кроки. Щодо цього існує не одностайний консенсус. Так, під час розгляду, рішенням більшості 5 проти 4 суддів Верховного Суду США було ухвалене рішення по справі, відомій, як «State v. Blake», в якій йдеться про правовідносини, у яких хтось випадково чи не усвідомлюючи став володіти забороненими ПАР НЗ, ПР, прекурсорами; справ щодо усіх минулих судимостей за зберігання ПАР; вимагають зняття старих та нових винесених вироків (а це, 
можливо, тисячі ув'язнених). Наслідками можуть стати потенційні відшкодування 3 боку судів за витрати та штрафи на мільйони доларів. Верховний суд зробив кардинальний крок до створення більш справедливої та гуманної системи кримінального правосуддя [40]. «Це великий крок, це велика справа», - сказав у недавньому інтерв'ю адвокат Mark Middaugh, який представляв Вашингтонську асоціацію адвокатів у кримінальних справах в одному з учасників судового засідання. «...Законодавчі збори не повинні поспішати із відновленням бойових дій у війні з наркотиками. Законодавчі збори мають чудову нагоду взяти паузу і натомість зосередитися на громадському здоров'ї та расовій справедливості» [40].

Натомість, Верховний суд штату Вашингтон виніс висновок у справі «Штат Вашингтон проти Блейка» (25.02.2021р.) та заявив, що RCW 69.50.4013 (Просте володіння Вашингтоном, Закон про контрольовані речовини) порушує положення про належну правову процедуру Конституції і тому немає юридичної сили. Роль Департаменту виправних установ штату Вашингтон полягає у виконанні вироків, ухвалених судами [41]. Департамент не має права змінювати чи виправляти судові рішення та вироки. Департамент не може в односторонньому порядку змінити вирок і повинен чекати, доки суд винесе ухвалу про скасування осуду, зміну вироку, звільнення або постанову про звільнення. Департамент працює з Генеральною прокуратурою, щоб зрозуміти рішення та його потенційні наслідки. За даними статистики, визначено низку потенційно порушених осіб із засудженням за просте зберігання ПАР та НЗ. Розрахункова кількість осіб станом на 28.02.2021 р., які постраждали за звинуваченням у простому володінні ПАР та НЗ: менше 100 осіб по всьому штату ув'язнено лише за простим звинуваченням у зберіганні ПАР та НЗ; менше 7000 осіб по всьому штату засуджено до громадського нагляду за простим звинуваченням у зберіганні ПАР та НЗ. Визначено ще один рівень осіб - особи, які мають судимість за просте зберігання ПАР НЗ та додаткову судимість. Розрахункова кількість осіб станом на 28.02.2021р., які зазнали звинувачення у простому володінні ПАР НЗ та додатковому засудженні: менше 2600 осіб у 
всьому штаті, які позбавлені волі на підставі простого засудження за зберігання ПАР НЗ та додаткових звинувачувальних вироків; менше 3900 осіб у всьому штаті, які несуть громадський нагляд щодо простого володіння ПАР НЗ та додаткової судимості. Департамент продовжить роботу із зацікавленими сторонами, залученими до судів, з метою оцінки впливу та наслідків справи «Держава проти Блейка», оскільки суди визначають, які справи, вироки та окремі особи порушені.

Як зазначає Чепурний Я. [42], за гучними цифрами, які так яскраво люблять презентувати правоохоронці, часто приховується зовсім інша реальність. Коли заради показників затримують не торговців ПАР, НЗ, ПР, прекурсорів (злочинців), а тих, хто від них страждає (хворих). Саме на наркозалежних (хворих) поліцейські і роблять основні показники, «... тобі вже погано, починає ламати, а вони починають: ось є крадіжка; давай - візьми; тобі умовно дадуть; загалом, дурили, а потім насправді - садять...». В статті підіймаються проблемні питання щодо захисту прав і свобод, життя і здоров'я людини і громадянина (Конституційна норма України), «...ви ж розумієте, що поліція це все кришує і буде кришувати; їм вигідно, щоб молодь помирала; помре так помре - це їх життя; кожен сам обирає свій шлях, тому у нас ніхто нікого рятувати не буде...» [42]. В подальшому судом було надано оцінку факту схиляння закупника до вживання ПАР НЗ і зроблено висновок про не доведення вини особи. Цей факт підтверджувався лише показаннями самого закупника, який заяву про вчинення злочину щодо нього не писав, потерпілим не визнаний, але при цьому зазначив, що вже давно вживає Н3 без будь-якого впливу з боку інших осіб, тобто є хворою людиною і потребує фармакотерапії адиктивної наркотичної залежності.

Рекомендації щодо захисту прав для проведення фармакотерапії та протидії незаконного обігу ПАР Н3 (якщо у вас в кишені або іншому місці вилучили Н3, які Вам не належать, або якщо вам підкинули Н3) приведено у статті [43]. 
Як відмічає Тарасова М., в Україні так і не прижилася західна модель ставлення до будь-яких форм «нездорового способу життя»- ставлення, що базується на допомозі, а не осуді. І хоча саме по собі вживання ПАР, НЗ, ПР, прекурсорів не є злочином, наркозалежних заздалегідь вважають злочинцями i намагаються закрити в камерах, сподіваючись, що таким чином суспільство стане здоровішим [44].

Як зазначається в статті Мамченко Н., використання доказів, отриманих унаслідок підбурювання з боку поліції, не можна виправдати суспільним інтересом, оскільки в такому випадку обвинувачений із самого початку може бути позбавлений права на справедливий судовий розгляд справи [45]. Про це йдеться в декількох рішеннях Європейського суду з прав людини (по справі «Тейксейра де Кастро проти Португалії», «Худобін проти Росії» тощо). Новий Верховний Суд за час своєї роботи ухвалив ряд рішень, які стосуються даної проблематики. Зокрема, в постанові від 06.03.2018 р. (справа №727/6661/15-к ККС) Верховний Суд відмітив, що відповідно до вимог Європейського суду 3 прав людини для відмежування провокації від допустимої поведінки правоохоронних органів $є$ низка критеріїв. Під змістовним критерієм розуміється наявність або відсутність суттєвих змістовних ознак, притаманних провокації правоохоронних органів, а під процесуальним критерієм - наявність у суду можливостей перевірити відомості про ймовірну провокацію під час судового засідання. Тобто, будь-яка інформація, що стосується існуючого наміру вчинити злочин або вчинюваного злочину, має бути такою, що здатна бути перевіреною, а державне обвинувачення повинно мати змогу продемонструвати на будь-якій стадії, що в його розпорядженні наявні достатні підстави для проведення оперативного заходу .

Розглянемо приклади із судово-фармацевтичної практики (СФП) щодо ризиків у фармакотерапії адиктивної залежності та протидії незаконного обігу ПАР в умовах пандемії COVID-19.

СФП 1. Встановлено, що судами Херсонської області різної інстанції розгляд кримінального провадження за обвинуваченням гр. Ф. у скоєнні 
злочинів, передбачених ч. 1, 2 ст. 307, ч. 1 ст. 315 КК України тривав більше 4 років [46]. Завдяки участі адвоката Зварич $Є$. Г., гр. Ф., який засуджувався в суді першої інстанції, але апеляційним судом кримінальна справа поверталася на новий розгляд, нарешті вступив в силу виправдувальний вирок, в якому зазначено, що суд у відповідності до рішення Європейського Суду з прав людини у справі «Раманаускас проти Литви» [47] встановив, що провокація з боку правоохоронних органів має місце тоді, коли відповідні працівники правоохоронних органів або особи, які діють за їхніми вказівками, не обмежуються пасивним розслідуванням, а з метою встановлення злочину, тобто отримання доказів і порушення кримінальної справи, впливають на суб'єкта, схиляючи його до вчинення злочину, який в іншому випадку не був би вчинений. Під час судового розгляду кримінального провадження було встановлено, що 22.09.2014 р. в ході оперативної закупки гр. Ф. був затриманий, в його сумці, в його квартирі, на балконі були вилучені гроші та ПР «амфетамін». Крім того гр. $\Phi$, начебто, схиляв особу, яка скоїла оперативну закупку до вживання ПАР. Обвинувачений гр. Ф. вину злочинах, які йому інкримінуються, заперечував, стверджував, що нікому заборонені для обігу ПАР не збував (не продавав), а гроші від «закупника» він отримував за придбання телефону. На момент фізичного затримання гр. Ф, в його сумці вилучили гроші та ПАР, але гр. Ф. стверджує, що сумку правоохоронці йому начепили пізніше. Разом з тим, гр. Ф. відмітив, що так само не було проблемою підкинути ПАР і на балкон, який знаходиться на першому поверсі будинка і не засклений. Тобто, все фактично все було спровоковано працівниками поліції.

СФП 2. Галицький суд м. Львова оголосив шістьом поліцейським підозру у вбивстві з необережності, прокуратура звинувачує їх у перевищенні службових обов’язків і ненаданні вчасно якісної медичної допомоги та фармакотерапії. Відкрито кримінальне провадження за статтею 365 Кримінального кодексу України (перевищення влади або службових обов'язків [48]. У ході слідства було встановлено, що працівники поліції (шестеро поліцейських Львівської роти тактико-оперативного реагування) у ніч проти 09.02.2018 р. прибули для 
перевірки грального закладу у центрі м. Львів, без будь-яких повідомлень про вчинення кримінального чи іншого правопорушення. Адже жодних викликів за цією адресою не було. Зайшовши у приміщення, підстав для здійснення обшуку в тієї чи іншої особи у них не було. Під час огляду в кишені одного з відвідувачів, 22-річного гр. К., патрульні помітили згорток. Спочатку чоловік намагався втекти. Попросили показати. Хлопець дістав і проковтнув даний пакет, вдавився ним. Причина смерті - механічна асфіксія. Там була ПАР НЗ. Застосувавши у подальшому безпричинні фізичні заходи впливу до потерпілого гр. К., перевищили свої повноваження. Завдавали тілесних ушкоджень, затягували руки пластиковими одноразовими затяжками, неодноразово кидали до землі, не надали своєчасно медичну допомогу та фармакотерапію, внаслідок чого особа померла. У той же час нагрудні камери поліцейських фіксували, що потерпілий опору не чинив, натомість повідомляв про погане самопочуття та просив про допомогу. Суд пояснив: поліцейські неправомірно застосували фізичну силу до постраждалого, вдягли на нього пластикові кайданки-стяжки. Тож самостійно допомогти собі чоловік не міг. Суд тривав 3,5 роки, нарешті 03.08.2021 головуючий суддя зачитав вирок суду, яким встановлено [49, 50], що у групі 6ти осіб, які перевищили владу або службові повноваження, будучи працівниками правоохоронного органу, умисно вчинили дії, які явно виходять за межі наданих їм прав та повноважень, які супроводжувались насильством, застосуванням спеціальних засобів та болісними і такими, що ображають особисту гідність потерпілого гр. К, за відсутності ознак катування, які спричинили тяжкі наслідки, внаслідок чого їх засуджено до 8 років за гратами, позбавлення усіх лейтенантського звання та заборона впродовж трьох років займати посади в державних органах влади; з виплатою на користь найближчих родичів загиблого понад 4 млн грн за моральну шкоду, яку стягнути 3 державного бюджету, на користь найближчих родичів загиблого; 3 компенсацією 3 власних коштів поліцейських 48 тис грн за проведення судових і криміналістичних експертиз [51]. 
СФП 3. Прокуратурою Дніпропетровської області спільно зі співробітниками управління внутрішньої безпеки Національної поліції та Служби безпеки України у Дніпрі викрито майора поліції під час одержання неправомірної вигоди та порушено кримінальну справу за ч. 3 ст. 368 КК України). Так, 28.08.2018 р. під час одержання другої частини неправомірної вигоди у розмірі 41 тис. грн зловмисника гр. А. було викрито правоохоронними органами. Встановлено, що гр. А., старший оперуповноважений підрозділу кримінальної поліції одного з районних відділів ГУ НП в Дніпропетровської області, вимагав від громадянина неправомірну вигоду у сумі 100000 грн за непритягнення останнього до кримінальної відповідальності за нібито зберігання Н3. У разі відмови поліцейський погрожував підкинути НЗ під час обшуку житла чоловіка. Наразі гр. А. повідомлено про підозру у скоєнні вказаного злочину та подано до суду клопотання про обрання запобіжного заходу у вигляді тримання під вартою. Досудове розслідування триває [52].

СФП 4. Прокуратура Миколаївської області розпочала кримінальне провадження за ч. 2 ст. 307 КК України [53]. Під час розслідування слідчим встановлено, що 28.02.2017 у Первомайському районі Миколаївської області оперативні працівники затримали 31-річного капітана поліції гр. Б., який підозрюється у тому, що підкинув місцевому мешканцю 160 грамів речовини, яка згідно судово-фармацевтичної експертизи віднесена до особливо небезпечного Н3, обіг якого заборонено - каннабіс (Таблиця I, Список №1 Постанови Кабінету Міністрів України № 770) [54]. Крім того, було встановлено, що до УВБ ГУ НП в Миколаївській області звернувся 29-річний мешканець Миколаївської області і розповів, що дільничний офіцер місцевої поліції змушує його піти на злочин, тобто «...щоб не псувати статистику по виявленню осіб, які зберігають ПАР, НЗ, ПР, прекурсори, старший дільничний, офіцер поліції почав підбурювати заявника побути в ролі наркозалежного і потримати у своєму будинку каннабіс. Дільничний пообіцяв сам принести чоловікові марихуану, потім прийти зі слідчим «виявити і вилучити» iï, i запевнив, що посприяє про уникнення відповідальності за це...» [53]. 
Наведені приклади із СФП щодо ризиків у протидії незаконного обігу ПАР, НЗ, ПР, прекурсорів свідчать про те, що проблема щодо фактів не доведення вини осіб, у яких правоохоронні органи вилучають ПАР, існує не тільки в Україні, а й у США.

На наступному етапі досліджень було розроблено та запропоновано нормотворчу ініціативу за результатами судово-фармацевтичного вивчення міжнародного досвіду щодо ризиків фармакотерапії адиктивної залежності та протидією незаконного обігу ПАР в умовах пандемії COVID-19. Нормотворча ініціатива торкалася редакційних змін до статті 309 КК України «Незаконне виробництво, виготовлення, придбання, зберігання, перевезення чи пересилання наркотичних засобів, психотропних речовин або їх аналогів без мети збуту» [55]. Запропоновано доповнити зміст статті 309 КК України словосполученням «для особистого вживання», що базується на принципі презумпції невинуватості, тобто коли особа не знає, що в вона $є$ носієм та зберігає ПАР, НЗ, ПР, прекурсори (Табл. 1).

За результатами тривалих судово-фармацевтичних досліджень, в період 3 1990 р. по листопад 2021 р., на підставі моніторингу, аналізу та систематизації кримінальних справ, судових вироків, судово-медичних, судово-наркологічних, судово-психіатричних і судово-фармацевтичних експертиз встановлено, що хворі на онкологічні захворювання, ВІЛ/СНІД, туберкульоз, шизофренія та епілепсія, психічні захворювання (особи з інвалідністю I та II груп, а також хворі, які працюють в лікувально-виробничих майстернях психоневрологічних i психіатричних закладів) мають відповідні пільги, тому захворювання «адиктивні залежності (наркотична, алкогольна та ін.» пропонуємо внести у Додаток 2 «Переліку категорій захворювань, у разі амбулаторного лікування яких ЛЗ відпускаються безоплатно» Постанови Кабінету Міністрів України від 17 серпня 1998 р. №1303 (у редакції постанови Кабінету Міністрів України від 26 серпня 2015 р. №759) «Про впорядкування безоплатного та пільгового відпуску лікарських засобів за рецептами лікарів у разі амбулаторного лікування окремих груп населення та за певними категоріями захворювань» [56]. 
Безоплатний відпуск ЛЗ за переліченими категоріями захворювань провадиться лише у разі амбулаторного лікування основного захворювання, за яким хворим надано пільги. Хворі на СНІД та ВІЧ-інфіковані незалежно від основного захворювання мають право на безоплатний відпуск ЛЗ за наявності в них будьяких інших захворювань.

Таблиця 1. Запропоновані нормотворчі зміни до статті 309 КК України.

\begin{tabular}{|c|c|c|}
\hline & $\boldsymbol{J}$ & \\
\hline 1 & 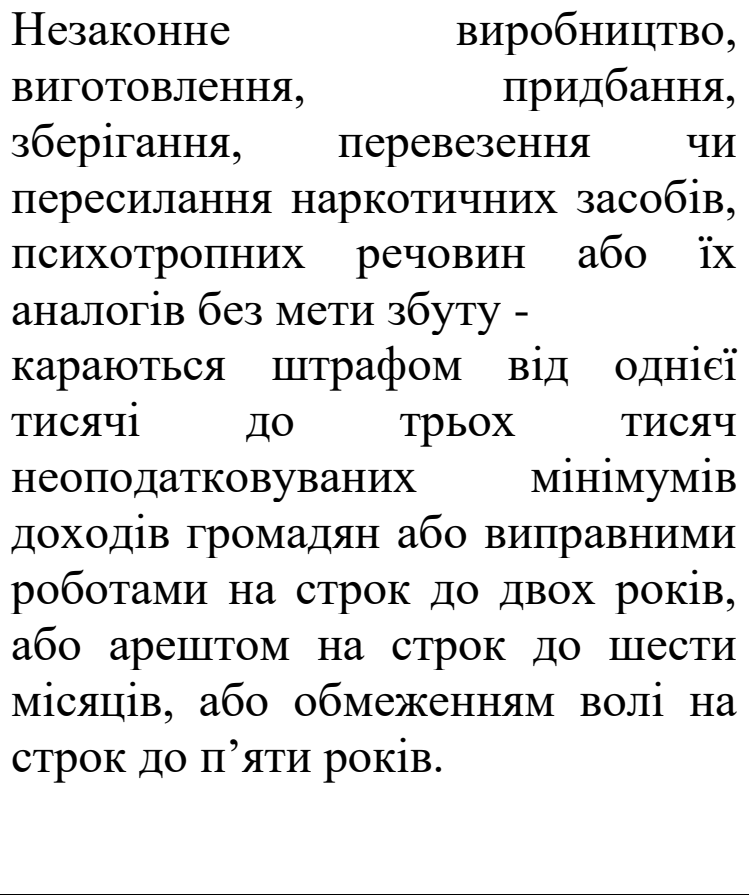 & 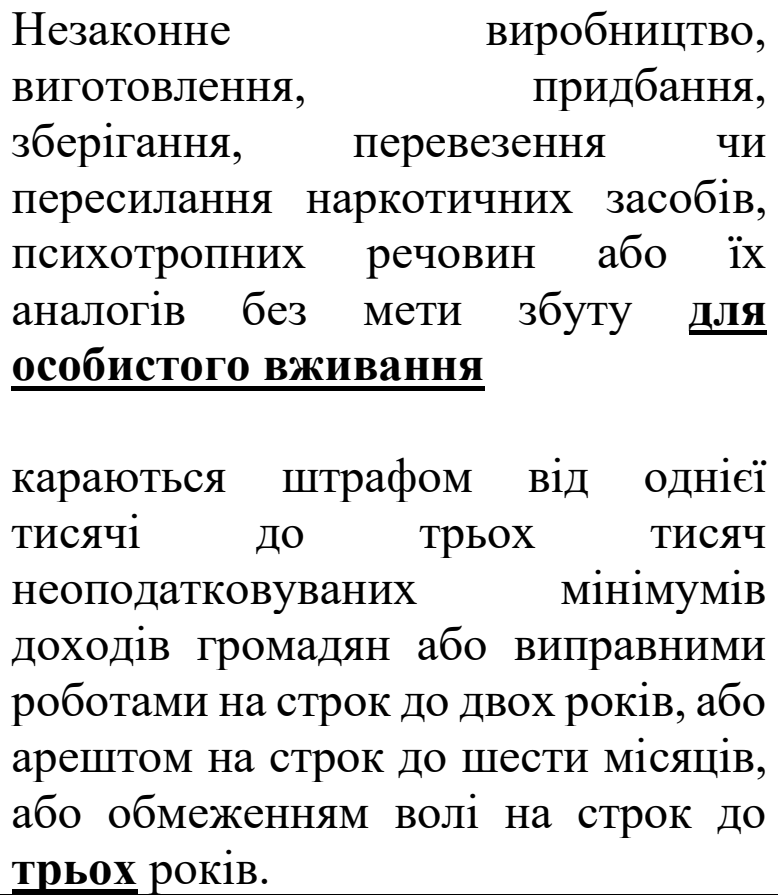 \\
\hline 2. & $\begin{array}{l}\text { Ті самі дії, вчинені за попередньою } \\
\text { змовою групою осіб чи протягом } \\
\text { року після засудження за цією } \\
\text { статтею або якщо предметом таких } \\
\text { дій були наркотичні засоби, } \\
\text { психотропні речовини або їх } \\
\text { аналоги у великих розмірах, - } \\
\text { караються штрафом від двох тисяч } \\
\text { до пяти тисяч неоподатковуваних } \\
\text { мінімумів доходів громадян або } \\
\text { позбавленням волі на строк до } \\
\text { трьох років. }\end{array}$ & $\begin{array}{l}\text { Ті самі дії, вчинені за попередньою } \\
\text { змовою групою осіб чи протягом } \\
\text { року після засудження за цією } \\
\text { статтею або якщо предметом таких } \\
\text { дій були наркотичні засоби, } \\
\text { психотропні речовини або іх } \\
\text { аналоги у великих розмірах, - } \\
\text { караються штрафом від двох тисяч } \\
\text { до п’яти тисяч неоподатковуваних } \\
\text { мінімумів доходів громадян або } \\
\text { позбавленням волі на строк від } \\
\text { трьох до п'яти років. }\end{array}$ \\
\hline 3. & $\begin{array}{lll}\text { Дiі, } & \text { передбачені } & \text { частинами } \\
\text { першою або другою } & \text { цієї статті, } \\
\text { вчинені } & \text { i3 } & \text { залученням }\end{array}$ & $\begin{array}{l}\text { Дії, передбачені частинами першою } \\
\text { або другою цієї статті, вчинені із } \\
\text { залученням неповнолітнього, a }\end{array}$ \\
\hline
\end{tabular}




\begin{tabular}{|c|c|c|}
\hline & $\begin{array}{l}\text { неповнолітньог, a також якщо } \\
\text { предметом таких дій були } \\
\text { наркотичні засоби, психотропні } \\
\text { речовини або іх аналоги в } \\
\text { особливо великих розмірах, - } \\
\text { караються позбавленням волі на } \\
\text { строк від п'яти до восьми років. }\end{array}$ & 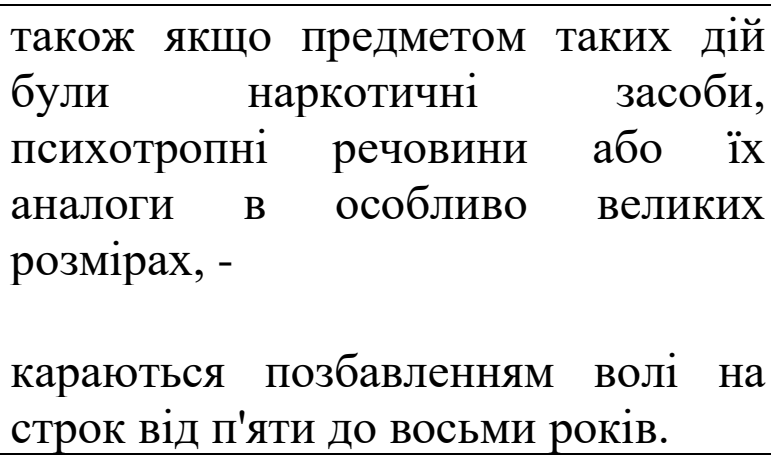 \\
\hline 4. & 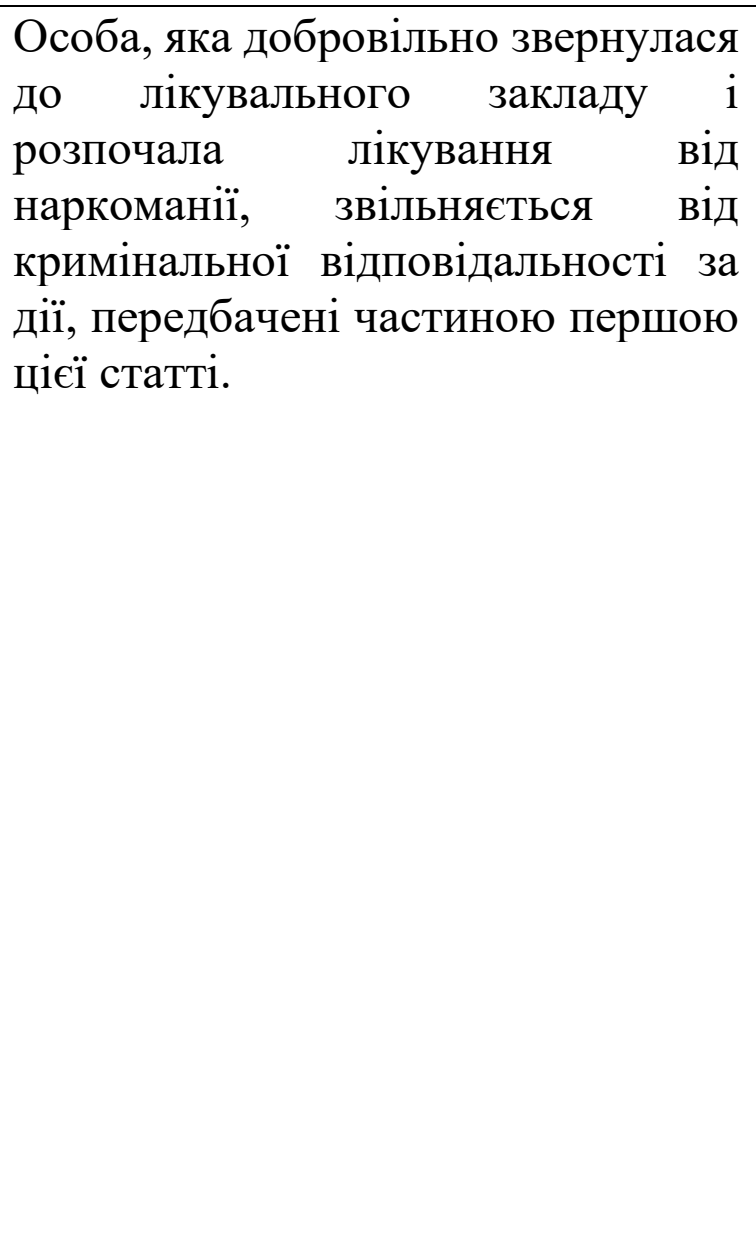 & 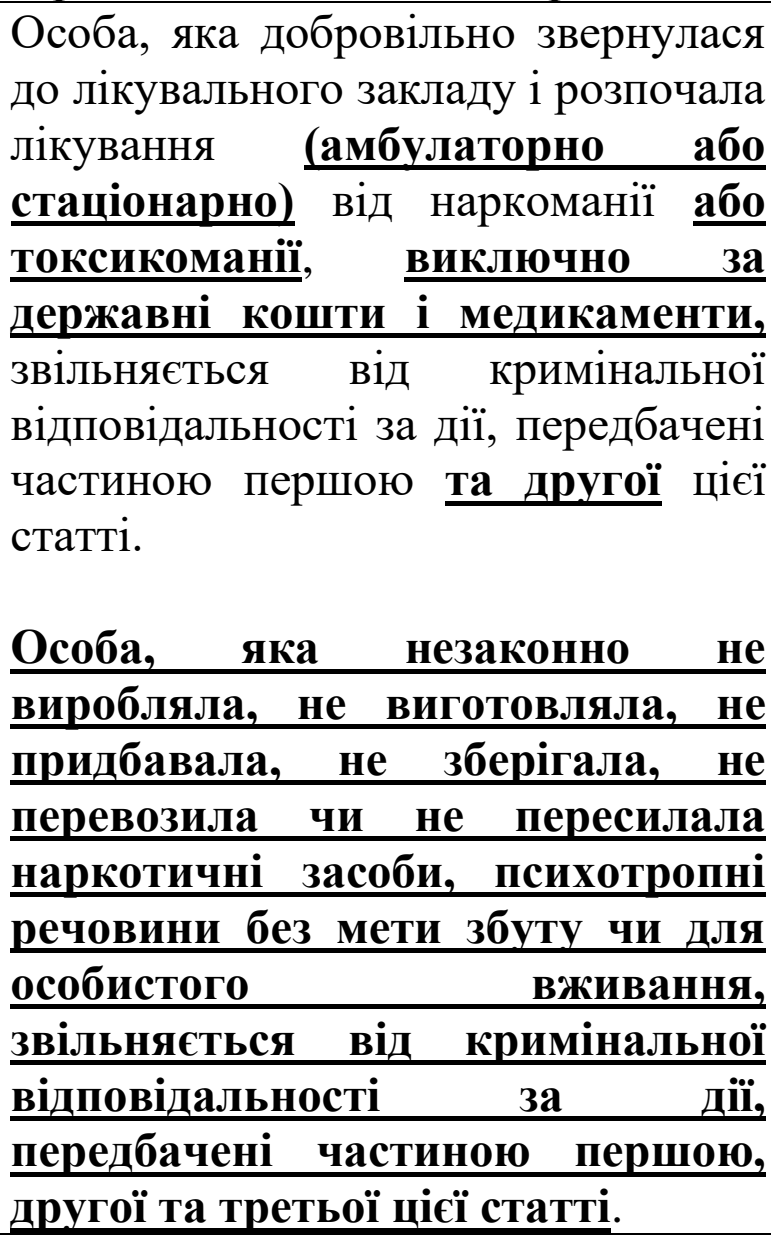 \\
\hline
\end{tabular}

За даними Сoyne C.J., Hall A.R. [57], прибічники заборони на обіг ПАР, Н3, ПР, прекурсорів стверджують, що така політика знижує злочинність, пов'язану 3 «наркотиками», знижує кількість пов'язаних із «наркобізнесом» захворювань та передозувань, а також $є$ ефективним засобом руйнування та ліквідації організованих злочинних груп. Натомість, будь яка заборона є неефективним, контрпродуктивним засобом задля досягнення цілей політиків. Беручи до уваги економічні висновки та доступні дані, доведено, що внутрішня війна 3 наркобізнесом сприяла збільшенню передозувань ПАР, НЗ, ПР, прекурсорів та створенню потужних наркокартелів. При цьому на міжнародному рівні також 
заборона не тільки не працює сама по собі, а й активно підриває цілі Глобальної війни з тероризмом. По-справжньому, ефективна реформа, пов'язана з протидією незаконного обігу ПАР, Н3, ПР, прекурсорів вимагатиме не тільки змін на рівні штатів, але, зрештою, вимагатиме критичних зрушень у федеральній політиці США як усередині країни, так і на міжнародному рівні [57].

Використання міжнародного досвіду щодо жорсткого покарання організаторів і членів злочинних наркоугруповань, осіб-рецидивістів і осіб, які втягують неповнолітніх у наркобізнес, незаконний обіг психоактивних речовин різних класифікаційно-правових груп, психоактивних ліків [58-62], при відповідному критичному підході може бути використаний в Україні з метою вдосконалення національного законодавства та реформування правової системи.

Окремої уваги набуває необхідність забезпечення права пацієнтів 3 адиктивною залежністю на тлі коронавірусної хвороби на доступну фармакотерпію (амбулаторно чи в умовах стаціонару) та соціально-економічну реабілітацію (пенсії, працевлаштування тощо за рахунок держави). В діях таких адиктивних пацієнтів можуть бути ознаки злочинів, передбачених ст. 309 КК України тому, що правоохоронна система (поліція, прокуратура, суди) не забезпечила ефективну протидію наркобізнесу щодо незаконного обігу в місцях масового перебування громадян.

Заходи протидії незаконному обігу ПАР, Н3, ПР, прекурсорів рекомендовано розробляти та впроваджувати одночасно на двох рівнях: верхньому (державна політика, законодавче, нормативно-правове регулювання) i нижньому (регулярні пропозиції до законодавства і законодавча ініціатива відомств, установ та організацій, органів державної влади та самоврядування, в першу чергу правоохоронних органів; планування конкретних антинаркотичних заходів тощо). Необхідно підняти рівень відповідальності і професійної підготовки прокурорів, поліцейських (слідчих, експертів) та інших оперативних служб в боротьбі з наркобізнесом, а також відповідним чином впливати на всі ланки незаконного обігу ПАР різних класифікаційно-правових груп: «збут попит - пропозиція - виробництво - зберігання - транспортування (перевезення 
- пересилка) - придбання - фіксація - документування - попередження припинення - вилучення - лікування - фармакотерапія».

Приклади із СФП свідчать про те, що випускники «поліцейських вузів» не адаптовані для протидії наркобізнесу в сучасних умовах, не враховують ризики ненадання своєчасної фармакотерпії на тлі поширення коронавірусної хвороби [63].

Акцентовано про актуальність під час пандемії на COVID -19 розробки додаткових заходів для удосконалення законодавства, нормативно-правових актів, а також контрольно-дозвільної системи щодо протидії поширення наслідків незаконного обігу ПАР, НЗ, ПР, прекурсорів, психоактивних ліків у вигляді адиктивної залежності та коморбідних ВІЛ/СНІДу, туберкульозу та ін. у відповідності до МКХ-11.

Висновки. Проведено судово-фармацевтичне вивчення міжнародного досвіду щодо ризиків у фармакотерапії адиктивної залежності та протидії незаконного обігу ПАР в умовах пандемії COVID-19. До ПАР віднесено Н3, ПР, прекурсори, психоактивні ліки. Зазначено, що в сучасних умовах пандемія на COVID-19 та його новий штам «Омікрон» посилює у всіх країнах світу протиепідемічні заходи, що вимагає від системи охорони здоров'я, насамперед України, зосереджувати сили закладів охорони здоров'я, фінанси і ліки для щеплення громадян всіх вікових груп, фармакотерапії коморбідних, супутніх, дуальних, адиктивних розладів на тлі коронавірусної хвороби. Вивчено досвід провідних країн світу щодо ризиків у поширенні незаконного обігу ПАР різних класифікаційно-правових груп. Встановлено, що попит на заборонені для обігу ПАР зростає, а глобалізація наркобізнесу стабілізується у вигляді транснаціональних організованних злочинних наркоугрупувань. Вказане викликає необхідність 3 боку законодавчих органів постійно посилювали кримінальну відповідальність за незаконний обіг ПАР, НЗ, ПР, прекурсорів, психоактивних ліків. Зазначено, що відповідні поліцейські й оперативні служби повинні постійно удосконалювати рівень і систему профілактики та боротьби 3 незаконним обігом ПАР. При цьому слід передбачити більш суворішу 
відповідальність за дії членів організованих злочинних наркоугрупувань з обігу з метою збуту (виробництва, модифікації зберігання, перевезення, пересилання торгівлі тощо) ПАР різних класифікаційно-правових груп 3 метою наживи у великих кількостях та особливо великих розмірах. Розроблено та запропоновано нормотворчі ініціативи до статті 307 Кримінального кодексу України.

Конфлікт інтересів. Автори засвідчують, що не мають конфлікту інтересів.

\section{Література.}

1. Shapovalova V.A., Zbrozhek S.I., Shapovalov V.V., Shapovalov V.V. Forensic pharmacy: some risk factors in the formation of addictive health disorders. Acta Scientific Pharmaceutical Science. 2021. V. 4. Iss. 1. P. 7-12. DOI: 10.3180/ASPS.2020.05.0651.

2. Shapovalov V.V. Forensic and pharmaceutical study of abuse and developing the principles of reducing the demand for psychoactive substances of different classification and regulatory groups. Farmatsevtychnyi zhurnal. 2014. No. 2. P. 39-47. 3. Shapovalov V.V. (mol.). Sudovo-farmatsevtychna otsinka nezakonnoho vzhyvannia kannabisu. Farmakom. 2014. No. 1. P. 86-92.

4. Tukhar I., Shapovalova V., Shapovalov V., Shapovalov V. Pharmacological view on the problem of comorbidity in the pharmacotherapy of chronic pancreatitis. Science Review. Vol.3. N.38. P.1-5. DOI: 10.31435/rsglobal_sr/30072021/7591.

5. Shapovalov V.V., Gudzenko A.A., Shapovalova V.A. et al. Forensic and pharmaceutical analysis of addictive morbidity because of the use of psychoactive substances in Ukraine. Klin.inform.telemed. 2020. Vol. 15. Iss. 16. P. 125-128. URL: https://doi.org/10.31071/kit2020.16.02.

6. V.A. Shapovalova, S.I. Zbrozhek, V.V. Shapovalov (Jr.) et al. Forensic and pharmaceutical study of causal relationships between social and medical risk factors in the formation of addictive health disorders. Health of Society. 2020. Is. 9.No. 6. P. 236242. DOI: https://doi.org/10.22141/2306-2436.9.6.2020.226954. 
7. Shapovalova V., Shapovalov V., Negretsky S. Forensic and pharmaceutical problems concerning circulation of cannabis: perspectives of state control, medical and narcological health effects. Actual problems of medicine and pharmacy. 2020. Vol. 1. N. 1-2. URL: https://apmplmi.com/index.php/apmp/article/view/17.

8. Shapovalov V.V. (Jr.), Shapovalova V.A., Shapovalov V.V. et al. Development of algorithms forensic training pharmaceutical seizures from illegal substance as an element of patient protection. European Applied Sciences. 2013. Vol. 2. N. 5. P. $197-$ 199.

9. Shapovalov V.V. (Jr.), Shapovalova V.A., Shapovalov V.V. et al. Forensic and pharmaceutical status of the determination of depending from cannabinoids (F12). European Applied Sciences. 2013. Vol. 2. N. 9. P. 146-149.

10. V. Shapovalov (Jr.), A. Gudzenko, L. Komar et al. Concerning the importance of forensic and pharmaceutical researches to improve patients' accessibility to medicines. Pharmacia. 2017. Vol. 65. N. 2. P. 23-29.

11. V. Shapovalov (Jr.), A. Gudzenko, V. Shapovalova et al. Forensic and pharmaceutical study of the presence of a causal link between the degree of alcohol abuse and qualification level of the respondents. Pharmacia. 2017. Vol. 66. N. 3. P. 31-39.

12. V. Shapovalov (Jr.), A. Gudzneko, V. Shapovalova et al. Forensic and pharmaceutical analysis of addictive morbidity because of the use of narcotic psychoactive substances in Ukraine (retrospective aspect). International Journal of Pharmaceutical Sciences and Research. 2018. Vol. 3; Is. 3. P. 22-25. URL: http://www.pharmacyjournal.net/archives/2018/vol3/issue3.

13. Chuiev Y., Shapovalova V. Interdisciplinary pharmacoeconomic study of pharmacotherapy of cupping of drunk forms of alcohol dependence: clinical and pharmacological, organizational, legal and marketing experiment. SSP Modern Pharmacy and Medicine. 2021. Vol. 1. N. 2. P. 1-12. URL: https://doi.org/10.53933/sspmpm.v1i2.24. 
14. Shapovalova V.A., Zbrozhek S.I., Shapovalov V.V. et al. Coronavirus disease pandemia 2019: growth of epidemic dangers. Acta scientific pharmaceutical sciences. 2020. Vol. 4. Iss. 7. P. 61-68.

15. Haiduchok I.H., Shapovalova V.O., Shapovalov Val. V., Shapovalov V.V. Rezhym kontroliu antybakterialnykh likarskykh zasobiv dlia farmakoterapii koronavirusnoi khvoroby (COVID-19) u patsiientiv $\mathrm{z}$ dualnymy rozladamy: informatsiinyi lyst pro novovvedennia. Ukrmedpatentinform MOZ Ukrainy. K.: Ukrmedpatentinform MOZ Ukrainy, 2020. N. 230-2020. 6 s.

16. Roberts M. What are the Delta, Gamma, Beta and Alpha Covid variants? BBC News. URL: https://www.bbc.com/news/health-55659820.

17. Callaway E. Heavily mutated coronavirus variant puts scientists on alert. Nature. 25.11.2021. URL:https://www.nature.com/articles/d41586-021-03552-w.

18. Order of the Cabinet of Ministers of Ukraine of August 28, 2013 No. 735-r "On approval of the Strategy of state drug policy until 2020" as amended and supplemented as of November 05, 2021. Cabinet of Ministers of Ukraine. URL: https://www.kmu.gov.ua/npas/246715472.

19. United Nations Millennium Declaration. Resolution adopted by the General Assembly. A/RES/55/2. United Nations. URL: https://undocs.org/en/A/RES/55/2.

20. World Drug Report 2021. United Nations Office on Drugs and Crime. URL: https://www.unodc.org/unode/en/data-and-analysis/wdr2021.html.

21. V.V. Shapovalov. The study of certain aspects of the modernization of the state of the healthcare industry of Ukraine on the basis of medical and pharmaceutical law. Farmatsevtychnyi zhurnal. 2013. No. 6. P. 28-35.

22. Shapovalova V. System of drugs circulation based on medical and pharmaceutical law. Actual problem of medicine and pharmacy. 2020. Vol. 1 No. 1-2. URL: https://apmplmi.com/index.php/apmp/article/view/12.

23. Shapovalov V.V. (Jr.), Gudzenko A.A., Andrieieva V.V. et al. Experience of the USA concerning and organization of healthcare system for the pharmaceutical provision for privileged categories of citizens. Annals of Mechnikov Institute. 2019. N. 
1. P. 81-87. DOI: 10.5281/zenodo.2639521. URL: http://www.imiamn.org.ua/journal/1_2019/PDF/13.pdf.

24. Naidoo P., Cele S. New Coronavirus Variant a 'Serious Concern' in South Africa. Bloomberg. URL: https://www.bloomberg.com/news/articles/2021-1125/who-meets-on-new-covid-19-variant-circulating-in-south-africa.

25. Hayduchok I.G. Innovation approaches to pharmacotherapy of systemic autoimmune diseases in the conditions of the COVID-19 pandemic. Likars 'ka Sprava. 2020. N. 7-8. P. 64-74. DOI: 10.31640/JVD.7-8.2020 (8).

26. Hayduchok I. Supportive pharmacotherapy for systemic autoimmune diseases with hyperimmunocomplex syndrome (experimental research). Georgian medical news. 2021. N. 9 (318). P. 159-165.

27. Hayduchok I. Pharmacotherapy of systemic autoimmune diseases in the convention of the COVID-19 pandemic: search for innovative technologies in the study. Acta Scientific Medical Science. 2021. Vol. 5. Iss. 9. P. 136-142. DOI: 10.31080/ASMS.2020.05.1022.

28. Hayduchok I. Pharmacotherapy of systemic vasculitis combined with cryoglobulinemic syndrome using pharmacoeconomic approaches. Global Journal of Health Science. 2021. Vol. 13. N. 7. P. 78-88. URL: https://doi.org/10.5539/gjhs.v13n7p78.

29. Hayduchok I. Pharmacotherapy of psoriasis support with antiphospholipid syndrome: ABC/VEN - analysis of anti-viral drugs. SSP Modern Pharmacy and Medicine. 2021. Vol. 1. Iss. 1. P. 1-12. DOI: https://doi.org/10.53933/sspmpm.v1i1.4. 30. Classification of Omicron (B.1.1.529): SARS-CoV-2 Variant of Concern. WHO. 26.11.2021. URL: https://www.who.int/news/item/26-11-2021-classification-ofomicron-(b.1.1.529)-sars-cov-2-variant-of-concern/.

31. WHO designates new COVID strain Omicron as 'variant of concern'. Aljazeera. URL: https://www.aljazeera.com/news/2021/11/26/who-designates-new-covid-strainomicron-variant-of-concern. 
32. WHO designates new COVID strain Omicron as 'variant of concern'. Gur

Times. URL: https://gurtimes.com/business/who-designates-new-covid-strainomicron-as-variant-of-concern/

33. Felter C. The U.S. Opioid Epidemic. CFR. URL: https://www.cfr.org/backgrounder/us-opioid-epidemic.

34. Tanno L.K., Chalmers R., Jacob R. at el. Global implementation of the World Health Organization's International Classification of Diseases (ICD)-11: The allergic and hypersensitivity conditions model. Allergy. 2020. N.75(9). P. 2206-2218. DOI: 10.1111/all.14468. URL: https://pubmed.ncbi.nlm.nih.gov/32578235/.

35. V.A. Shapovalova, V.V. Shapovalov, V.V. Shapovalov et al. Forensic and pharmaceutical assessment of polydrug addiction at combined use of psychoactive substances. Likars'ka sprava. 2018. N. 1-2 (1146). P. 171-177. DOI: 10.31640/JVD.12.2018(29).

36. Erler Carolyn. Targeting "Plan Colombia": A Critical Analysis of Ideological and Political Visual Narratives by the Beehive Collective and the Drug Enforcement Administration Museum. Studies in Art Education, Vol. 50, No. 1, National Art Education Association, 2008. P. 83-97. URL: https://www.jstor.org/stable/25475888. 37. The war against drugs and the interests of governments. Senate of Canada. URL: https://sencanada.ca/content/sen/committee/371/ille/presentation/labrousse-e.htm.

38. Drug trends across Washington: Crime lab data. The Addictions, Drug \& Alcohol Institute. URL: https://adai.washington.edu/wadata/stateMOP_cases.htm.

39. Collins F. The Status of Drug Possession in Washington State. MRSC. URL: https://mrsc.org/Home/Stay-Informed/MRSC-Insight/March-2021/The-Status-ofDrug-Possession-in-Washington-State.aspx/.

40. Sara Jean Green Now that Washington's drug possession law has been struck down, swamped legal system faces massive do-over. Seattle Times. URL: https://www.seattletimes.com/seattle-news/washingtons-drug-possession-law-hasbeen-deemed-unconstitutional-heres-what-the-legal-system-is-grappling-with-now/. 
41. Press release: Update on Supreme Court Ruling That Voids Statute Has Potential Implications for Sentences Imposed by Courts. Washington State Department of Corrections. URL:https://doc.wa.gov/news/2021/03122021p.htm.

42. Chepurnyi Ya. Na holtsi pokaznykiv. Tsentr zhurnalistskykh rozsliduvan (Mykolaiv). URL: https://investigator.org.ua/ua/publication/207814/.

43. Novhorodskyi A. Pidkynuly narkotyky? Instruktsiia, yak diiaty, shchob ne potrapyty za hraty! Legal Advice. URL: https://www.pravoconsult.com.ua/pidkinulinarkotiki/.

44. Tarasova M. Prezumptsiia vynuvatosti narkozalezhnykh. ZN.UA. URL: https://zn.ua/ukr/SOCIUM/prezumpciya-vinuvatosti-narkozalezhnih-yakspozhivachi-narkotikiv-stayut-universalnimi-pidozryuvanimi-v-ochahpravoohoronciv-i-scho-z-nimi-vidbuvayetsya-pislya-areshtu-_html 45. Mamchenko N. Provokatsiia zlochynu: praktyka Verkhovnoho Sudu. Sudebnoyurydycheskaia hazeta. URL: https://sud.ua/ru/news/publication/118480provokatsiya-zlochinu-praktika-verkhovnogo-sudu.

46. Zavdiaky sumlinnii roboti advokata, dii pravookhorontsiv pry provedenni operatyvnoi zakupivli buly vyznani provokatsiieiu. Bezoplatna pravova dopomoha. URL:https://www.legalaid.gov.ua/novyny/zavdyaky-sumlinnij-roboti-advokata-diyipravoohorontsiv-pry-provedenni-operatyvnoyi-zakupivli-buly-vyznaniprovokatsiyeyu/.

47. Case of Ramanauskas v. Lithuania (No. 2) (Application no. 55146/14). European Court of Human Rights. URL: http://hudoc.echr.coe.int/eng?i=001-180850. 48. Tereshchuk H. Shist politseiskykh Lvova pid domashnim areshtom. Radio Svoboda. URL: https://www.radiosvoboda.org/a/29226486.html

49. Shykula M. Radion Ye. podavyvsia narkotykamy: u Lvovi politseiskykh zasudyly do 8 rokiv za gratamy cherez smert yunaka. 5.UA. URL: https://www.5.ua/regiony/podavyvsia-narkotykamy-u-lvovi-politseiskykh-zasudylydo-8-rokiv-za-gratamy-cherez-smert-iunaka-251200.html.

50. Molodyi khlopets mih zadushytysia paketykom iz kanabisom cherez nasylstvo shistokh politseiskykh - yikh zasudyly do 8 rokiv viaznytsi. Sudreporter. URL: 
https://sudreporter.org/molodyj-hlopecz-mig-zadushytysya-paketykom-iz-kanabisomcherez-nasylstvo-shistoh-policzejskyh-yih-zasudyly-do-8-rokiv-vyaznyczi/.

51. Case No. 461/1593/1. Sentence in the name of Ukraine. Halych District Court of Lviv. URL: https://reyestr.court.gov.ua/Review/98753667.

52. U Dnipri politseiskyi, yakyi pidozriuietsia u vymahanni 100000 hryven khabara, opynytsia pid vartoiu. Dnipropetrovsk Region Prosecutor's Office. URL: https://dnipr.gp.gov.ua/ua/news.html?_m=publications\&_t=rec\&id=235743\&fp=180.

53. Na Mykolaivshchyni kapitan politsii pidkynuv narkotyky mistsevomu dlia pidvyshchennia pokaznykiv svoiei roboty. TSN. URL: https://tsn.ua/ukrayina/namikolayivschini-kapitan-policiyi-pidkinuv-narkotiki-miscevomu-dlya-pidvischennyapokaznikiv-svoyeyi-roboti-889100.html.

54. Resolution of the Cabinet of Ministers of Ukraine of May 6, 2000 No. 770 "On Approval of the List of Narcotic Drugs, Psychotropic Substances and Precursors" as amended and supplemented as of November 20, 2021. Verkhovna Rada of Ukraine. 09.04.2021. URL:https://zakon.rada.gov.ua/laws/show/770-2000-\%D0\%BF\#Text.

55. Criminal Code of Ukraine as amended and supplemented as of November 20, 2021. 2001. Verkovna Rada of Ukraine. URL: https://zakon.rada.gov.ua/laws/show/2341-14\#Text.

56. Resolution of the Cabinet of Ministers of Ukraine of August 17, 1998 No. 1303 "On streamlining free and preferential dispensing of medicinal products subject to medical prescriptions in the case of outpatient treatment of certain groups of the population and for certain categories of diseases" as amended and supplemented as of November 20, 2021. Verkhovna Rada of Ukraine. URL: https://zakon.rada.gov.ua/laws/show/1303-98-\%D0\%BF\#Text.

57. Coyne C.J. Hall A.R. Four decades and counting: the continued failure of the war on drugs. Policy analysis No. 811. CATO Institute. URL: https://www.cato.org/policy-analysis/four-decades-counting-continued-failure-wardrugs.

58. Legal Framework for Drug Trafficking. United Nations Office on Drugs and Crime. URL: https://www.unodc.org/unodc/en/drug-trafficking/legal-framework.html 
59. Lee N. America has spent over a trillion dollars fighting the war on drugs. 50 years later, drug use in the U.S. is climbing again. CNBC. URL: https://www.cnbc.com/2021/06/17/the-us-has-spent-over-a-trillion-dollars-fightingwar-on-drugs.html.

60. Mann B. After 50 years of the war on drugs, what good is it doing for us? Npr. URL: $\quad$ https://www.npr.org/2021/06/17/1006495476/after-50-years-of-the-war-ondrugs-what-good-is-it-doing-for-us.

61. Shapovalov V.V., Omelchenko V.O., Shapovalova V.O. Doslidzhennia stanu narkotyzatsii suspilstva na prykladi zlovzhyvannia opioidnymy narkotychnymy zasobamy (sudovo-farmatsevtychni aspekty). Farmakom. 2016. №3, dodatok. S. 4968.

62. DEA Announces Review of International Operations. United States Drug Enforcement Administration. URL: https://www.dea.gov/pressreleases/2021/08/26/dea-announces-review-international-operations.

63. COVID pandemic fuelling major increase in drug use worldwide: UN report. United Nations. URL: https://news.un.org/en/story/2021/06/1094672. 